\title{
Bacterial Community Dynamics During the Application of a Myxococcus xanthus-Inoculated Culture Medium Used for Consolidation of Ornamental Limestone
}

\author{
Guadalupe Piñar • Concepcion Jimenez-Lopez • Katja Sterflinger • Jörg Ettenauer • \\ Fadwa Jroundi • Antonia Fernandez-Vivas • Maria Teresa Gonzalez-Muñoz
}

Received: 17 September 2009 / Accepted: 17 March 2010/Published online: 15 April 2010

(C) The Author(s) 2010. This article is published with open access at Springerlink.com

\begin{abstract}
In this study, we investigated under laboratory conditions the bacterial communities inhabiting quarry and decayed ornamental carbonate stones before and after the application of a Myxococcus xanthus-inoculated culture medium used for consolidation of the stones. The dynamics of the community structure and the prevalence of the inoculated bacterium, M. xanthus, were monitored during the time course of the consolidation treatment (30 days). For this purpose, we selected a molecular strategy combining fingerprinting by denaturing gradient gel electrophoresis (DGGE) with the screening of eubacterial 16S rDNA clone libraries by DGGE and sequencing. Quantification of the inoculated strain was performed by quantitative real-time PCR (qPCR) using M. xanthus-specific primers designed in this work. Results derived from DGGE and sequencing analysis showed that, irrespective of the origin of the stone, the same carbonatogenic microorganisms were activated by the application of a M. xanthus culture. Those microorganisms were Pseudomonas sp., Bacillus sp., and Brevibacillus sp. The monitoring of M. xanthus in the culture media of treated stones during the time course experiment showed disparate results depending on the applied technique. By culture-dependent methods, the detection of this bacterium was only possible in the first day of the treatment,
\end{abstract}

G. Piñar $(\bowtie) \cdot K$. Sterflinger $\cdot$ J. Ettenauer

Institute of Applied Microbiology, Department of Biotechnology, University of Natural Resources and Applied Life Sciences,

Muthgasse 18,

1190 Vienna, Austria

e-mail: guadalupe.pinar@univie.ac.at

C. Jimenez-Lopez $\cdot$ F. Jroundi $\cdot$ A. Fernandez-Vivas

M. T. Gonzalez-Muñoz

Department of Microbiology, University of Granada,

Fuentenueva s/n,

18071 Granada, Spain showing the limitation of these conventional techniques. By PCR-DGGE analysis, $M$. xanthus was detected during the first 3-6 days of the experiment. At this time, the population of this bacterium in the culture media varied between $10^{8}$

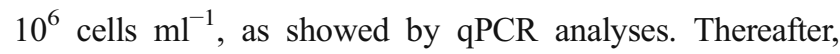
DGGE analyses showed to be not suitable for the detection of $M$. xanthus in a mixed culture. Nevertheless, qPCR analysis using specific primers for M. xanthus showed to be a more sensitive technique for the detection of this bacterium, revealing a population of $10^{4}$ cells $\mathrm{ml}^{-1}$ in the culture media of both treated stones at the end of the consolidation treatment. The molecular strategy used in this study is proposed as an effective monitoring system to evaluate the impact of the application of a bacterially induced carbonate mineralization as restoration/conservation treatment for ornamental stones.

\section{Introduction}

Conventional treatments, both inorganic as well as organic, used for the protection and consolidation of ornamental stones have yielded poor results due to the incompatibility between the treated stone and the nature of the material applied in the treatment. In many cases, treatments have in fact proved harmful by accelerating the alteration [13]. In contrast, consolidation methods based on the biomineralization capability of some microorganisms have shown to be more successful than traditional methods. Several groups have investigated the potential of different microorganisms to be used as biomineralization agents $[12,13,53]$. In this regard, for instance, Castanier et al. [6] and Orial et al. [33] used Bacillus cereus to consolidate stone surfaces. They found that $B$. cereus was able to induce extracellular precipitation of calcium carbonate on decayed limestones. 
This calcium carbonate was compatible with the substrate and significantly reduced the water absorption of the treated stone. However, the layer of the new cement induced by $B$. cereus consisted of only few microns.

Alternatively, Rodriguez-Navarro et al. [42] proposed another bacterial conservation method based on the use of Myxococcus xanthus. This method appears to be more effective than that proposed by Castanier et al. [6]. The Gram-negative, non-pathogenic, common soil bacterium, M. xanthus ( $\delta$-subdivision of the Proteobacteria), is able to induce the extracellular precipitation of calcium carbonate [42]. The metabolic activity of $M$. xanthus results in the production of $\mathrm{CO}_{2}$ and $\mathrm{NH}_{3}$. Extracellular ammonia release raises $\mathrm{pH}$ values and therefore $\mathrm{CO}_{3(\mathrm{aq})}{ }^{2-}$ concentration, according to these equilibria:

$$
\begin{aligned}
& \mathrm{NH}_{3(g)}+\mathrm{H}_{2} \mathrm{O} \Leftrightarrow \mathrm{NH}_{4(a q)}^{+}+\mathrm{OH}_{(a q)}^{-} \\
& \mathrm{CO}_{2(g)}+\mathrm{H}_{2} \mathrm{O}_{(1)} \Leftrightarrow \mathrm{H}_{2} \mathrm{CO}_{3(a q)} \Leftrightarrow \mathrm{HCO}_{3(a q)}^{-}+H_{(a q)}^{+} \\
& \quad \Leftrightarrow \mathrm{CO}_{3(a q)}^{2-}+2 \mathrm{H}_{(a q)}^{+}
\end{aligned}
$$

Precipitation of a calcium carbonate phase occurs when a sufficient supersaturation is reached with respect to this phase [43]:

$$
\mathrm{Ca}_{(a q)}^{2+}+\mathrm{CO}_{3(a q)}^{2-} \Leftrightarrow \mathrm{CaCO}_{3(s)}
$$

The newly formed calcium carbonate creates a coherent carbonate cement of $10-50 \mu \mathrm{m}$ coating the treated stones. Moreover, this cement is rooted down to a depth of $1 \mathrm{~mm}$ while, at the same time, the porosity of the stone remains unaltered [42].

Recently, Jimenez-Lopez et al. [18, 19] investigated the role of the natural microbial community inhabiting decayed and quarry calcarenites when either a sterile specific culture medium or a culture inoculated with $M$. xanthus was applied to consolidate both kind of stones. Authors compared the chemical evolution of the culture medium, calcium carbonate precipitation, and stone consolidation on both decayed and quarry calcarenites during the consolidation treatment. The culture media used in these studies were partially selective due to the introduction of only peptones as a source of carbon and nitrogen, thus enhancing, among the microbial community inhabiting the stone, the growth of chemoorganotrophic bacteria that make use of the amino acids as a source of these both macronutrients. The oxidative deamination of the amino acids induced an increase on the $\mathrm{pH}$ of the system as a consequence of the release of $\mathrm{NH}_{3}$, thus creating favorable conditions for calcium carbonate precipitation. Jimenez-Lopez et al. [18, 19] demonstrated that the bacteria activated from the natural microbial community of the stone were able to induce the precipitation of $\mathrm{CaCO}_{3}$ cement that was compatible with the substrate and consolidated the porous limestone without pore plugging. These results were improved when $M$. xanthus was present.

Nevertheless, and with the goal of the potential application of a $M$. xanthus-inoculated culture medium to treat ornamental stone in situ, it is necessary to develop a sustainable monitoring system to evaluate the effects on the microbial community inhabiting a stone during the application of such a treatment. This monitoring will allow to develop a more efficient consolidation method and to reduce the time needed for the treatment, thus reducing costs and the risk of potential contaminations. Therefore, in the present study, we propose the application of a molecular strategy, as monitoring system, to investigate (a) the microbial communities inhabiting both quarry and decayed ornamental porous limestone prior any consolidation treatment, (b) the dynamics of the community structure during the application of a M. xanthusinoculated culture medium, and (c) the prevalence of the inoculated strain, $M$. xanthus, on such stone in which the autochthonous microbiota has not been eliminated.

The proposed molecular strategy combines fingerprinting by denaturing gradient gel electrophoresis (DGGE) with the screening of eubacterial 16S rDNA clone libraries by DGGE and sequencing. Furthermore, the quantification of $M$. xanthus is performed by quantitative real-time PCR (qPCR) using $M$. xanthus-specific primers designed in this work.

\section{Methods}

Stone Slabs, Inoculum, and Culture Medium

Two sets of porous limestone slabs $(2 \times 5 \times 0.5 \mathrm{~cm})$ cut out from "quarry calcarenite" and "decayed calcarenite" were used. The quarry calcarenite was collected from La Escribanía (Escúzar, Spain). The decayed calcarenite was collected from a large, thoroughly decayed pinnacle once placed at the Granada Cathedral (Spain) and substituted during one restoration intervention performed over the early 1990s of the twentieth century (for more details about both types of calcarenite, see references $[18,19])$. One piece of each set of slabs from quarry (Q) and decayed (D) stone, here referred as non-treated stone samples, was reserved for molecular analyses prior the treatment.

The microorganism used as inoculum was $M$. xanthus (strain number 422, Spanish Type Culture Collection, Burjasot, Valencia, Spain), cultured in liquid CT [42], and incubated at $18.85 \mathrm{rad} \mathrm{s}^{-1}$ for $48 \mathrm{~h}$ at $28^{\circ} \mathrm{C}$.

Biomineralization test was conducted in M-3P culture medium with the following composition: 1 wt.\% $\mathrm{Ca}$ $\left(\mathrm{CH}_{3} \mathrm{COO}\right)_{2} \cdot 4 \mathrm{H}_{2} \mathrm{O}, 0.2$ wt. $\% \mathrm{~K}_{2} \mathrm{CO}_{3} \cdot 1 / 2 \mathrm{H}_{2} \mathrm{O}, 10 \mathrm{mM}$ phosphate buffer in distilled water, $\mathrm{pH} 8$ [42]. Carbohydrates were excluded from the culture medium, while $1 \mathrm{wt} . \%$ Bacto 
Casitone was introduced as the sole source of carbon and nitrogen. Removal of carbohydrates excludes the growth of microorganisms that produce organic acids as the result of their metabolism and enhances the growth of bacteria that use amino acids as $\mathrm{C}$ and $\mathrm{N}$ source.

\section{Experimental Procedure}

Sixteen 250-ml Erlenmeyer flasks containing $100 \mathrm{ml}$ of M3-P medium filtered and sterilized were used in the experiment. Eight of these flasks were dedicated to runs involving quarry calcarenite slabs and eight to decayed calcarenite ones. In those runs involving quarry stone, one slab of non-sterile quarry calcarenite was introduced on each of the eight flasks. The same holds true for runs involving decayed calcarenite.

Out of each group of eight, four of the Erlenmeyer flasks were inoculated with $2 \mathrm{ml}$ of $M$. xanthus inoculum (cell density $\sim 3 \times 10^{8}$ cells ml $^{-1}$ ), and the remaining four Erlenmeyer flasks were kept sterile, acting as a controls. Therefore, four replicas of each experiment were carried out. Three of these replicas were used to study both the chemistry of the culture medium and the consolidation achieved on the stones, as showed in the studies performed by Jimenez-Lopez et al. [18, 19]. The remaining one replica was solely devoted to the molecular analysis of both the culture medium and the stones, as showed in the present study. No sampling other than that specified below was performed on this replica to avoid potential contamination.

All Erlenmeyer flasks were incubated in the dark at $28^{\circ} \mathrm{C}$ for 30 days in a rotary shaker at $5.97 \mathrm{rad} \mathrm{s}^{-1}$. Shaking was performed to ensure enough homogenization and aeration of the flask. At predetermined time intervals $(0,1,2,3,6,8,10$, $15,20,25$, and 30 days), an aliquot of $2 \mathrm{ml}$ of culture media was collected from the Erlenmeyer flasks under aseptic conditions, centrifuged at $1,571.05 \mathrm{rad} \mathrm{s}^{-1}$ for $5 \mathrm{~min}$, and the pellet was stored at $-80^{\circ} \mathrm{C}$ for further molecular analyses of the microbiota growing in the culture medium. At the end of the experiment, treated quarry (referred as TQ) and decayed (referred as TD) stone slabs were collected, rinsed twice using distilled water, and dried in an oven at $40^{\circ} \mathrm{C}$ for $48 \mathrm{~h}$. A piece of each stone was separated and stored in a sterile Petri dish for molecular analyses.

The presence of $M$. xanthus was also investigated by a culture-dependent approach. A volume of $0.5 \mathrm{ml}$ of the culture medium in which the stone (both quarry and decayed) was being treated was collected at each time interval mentioned above during the time course experiment. Serial decimal dilutions were performed, and three Petri dishes containing M3-P solid culture medium (liquid M3-P medium supplied with $1.8 \%$ agar agar, Difco) were inoculated with $0.1 \mathrm{ml}$ of each dilution.
DNA Extraction and PCR Analyses

Genomic DNA was extracted directly from stone slabs (nontreated and treated) as well as from the $2 \mathrm{ml}$ collected from the culture media of treated samples as described by SchabereiterGurtner et al. [48]. Briefly, cells were lysed enzymatically with lysozyme and proteinase $\mathrm{K}$ and then treated with a SDS-based lysis at $65^{\circ} \mathrm{C}$ in a final buffer concentration of $100 \mathrm{mM} \mathrm{Na} 2$ EDTA, $100 \mathrm{mM}$ Tris- $\mathrm{HCl}, 100 \mathrm{mM} \mathrm{Na}$ phosphate buffer ( $\mathrm{pH} 8.0$ ), $1.5 \mathrm{M} \mathrm{NaCl}, 1 \%$ CTAB (hexadecyltri-methyl ammonium bromide), and 1.5\% SDS. Samples were next subjected to 3 cycles of freezing $\left(-80^{\circ} \mathrm{C}\right)$ and thawing $\left(65^{\circ} \mathrm{C}\right)$ to break cells mechanically. Afterwards, the DNA was purified with the QIAamp Viral RNA Mini Kit (Qiagen) as recommended by the manufacturers.

For PCR analysis, $2 \times$ PCR Master Mix (Promega; $50 \mathrm{U} \mathrm{ml}^{-1}$ of Taq DNA polymerase supplied in a proprietary reaction buffer $(\mathrm{pH} 8.5), 400 \mu \mathrm{M}$ dATP, $400 \mu \mathrm{M}$ dGTP, $400 \mu \mathrm{M}$ dCTP, $400 \mu \mathrm{M}$ dTTP, $3 \mathrm{mM}$ $\mathrm{MgCl} 2$ ) was diluted as recommended by the manufacturers, and 12.5 pmol of each primer was added. PCR was carried out in $25-\mu 1$ volumes, and $2 \mu 1$ DNA template was added.

Two different PCR reactions were carried out to amplify eubacterial $16 \mathrm{~S}$ rDNA fragments. In a first amplification, DNA was amplified with the primer pairs 341f/907r [26, 52] or 341f/1492r [26]. For DGGE analysis, 200-bp fragments of the 16S rDNA were amplified with a nested PCR using the eubacterial-specific primer $341 \mathrm{f}-\mathrm{GC}$ (forward) to which a 40-base GC clamp was added to its $5^{\prime}$ end [31]. As reverse primer, the universal consensus primer 518r [32] was used. PCR reactions were performed using a Robocycler (Stratagene). PCR conditions were as described by Schabereiter-Gurtner et al. [48].

DNA of $M$. xanthus was amplified with the specific primer pair Frz799 (5'-GTGGACCTCCTCTTCTTCGA CATC-3') and Frz1147 (5'-GACATGTGTCT CAGTGCCTTCCTT-3') designed in this study with the Primer3 program (http://primer3.sourceforge.net/) [46], which specifically amplifies 349 bp of the frzABCD gene. The $f r z$ genes are involved in aggregation and fruiting body formation of $M$. xanthus [8]. Primers were further tested for specificity with the PrimerBlast program [46].

The specificity of the PCR assay was examined by using bacterial DNAs of other bacterial taxons, including the $\alpha$-Proteobacterium Methylobacterium rhodesianum (environmental isolate), the $\beta$-Proteobacterium Nitrosomonas sp. (environmental isolate), the $\gamma$-Proteobacteria Pseudomonas stutzeri (DSM 5190), and Pseudomonas putida (DSM 291), the $\delta$-Proteobacteria Desulfovibrio desulfuricans (environmental isolate) and M. xanthus (CECT422), the Firmicutes Bacillus megaterium (DSM 32), Bacillus pumilus (DSM 27), Bacillus flexus (DSM 1320), and 
Brevibacillus brevis (environmental isolate), and the Actinobacteria Kocuria rosea and Micrococcus luteus (environmental isolates).

PCR conditions: 5 -min denaturation $\left(95^{\circ} \mathrm{C}\right)$, followed by 35 cycles consisting of 1 -min denaturation $\left(95^{\circ} \mathrm{C}\right), 1$-min primer annealing $\left(56^{\circ} \mathrm{C}\right)$, and 1-min primer extension $\left(72^{\circ} \mathrm{C}\right)$, with a final extension step of $72^{\circ} \mathrm{C}$ for $5 \mathrm{~min}$.

\section{DGGE Analysis}

DGGE was performed as previously described [31] using a D-Code system (Bio-Rad) in $0.5 \times$ TAE $(20 \mathrm{mM}$ Tris, $10 \mathrm{mM}$ acetate, $0.5 \mathrm{mM} \mathrm{Na}_{2} \mathrm{EDTA}$; $\mathrm{pH}$ 7.8). The optimized lineal chemical gradient used ranged from $30 \%$ to $55 \%$ (100\% denaturants contains $7 \mathrm{M}$ urea and $40 \%\left(\mathrm{vol} \mathrm{vol}^{-1}\right)$ formamide). Gels electrophoretic separation was performed at a constant temperature $\left(60^{\circ} \mathrm{C}\right)$ and $200 \mathrm{~V}$ for $3.5 \mathrm{~h}$. Subsequently, gels were stained in an ethidium bromide solution $\left(1 \mu \mathrm{g} \mathrm{ml}^{-1}\right)$ for $15 \mathrm{~min}$ and visualized by a UVP documentation system (Bio-Rad Transilluminator, Universal Hood; Mitsubishi P93D-printer).

Cloning of PCR Products and Screening of Inserts by PCRDGGE Analysis

Five microliters of the purified PCR product (QIAquick PCR purification kit, Qiagen), amplified with primers 341f and $907 \mathrm{r}$, were cloned directly with the pGEM-T Vector System (Promega, Mannheim, Germany), following the protocol of the manufacturer. The ligation product was subsequently transformed into $E$. coli XLI-Blue which allows blue-white screening and plated on LB medium containing ampicillin $\left(100 \mu \mathrm{g} \mathrm{ml} \mathrm{m}^{-1}\right)$, tetracycline $\left(10 \mu \mathrm{g} \mathrm{ml}^{-1}\right)$, X-Gal $(0.1 \mathrm{mM})$, and IPTG $(0.2 \mathrm{mM})$ [47].

The obtained clone libraries were screened by comparing the migration of reamplified inserts by DGGE analyses [48]. Clones showing different positions in DGGE were selected for sequencing.

Sequencing and Comparative Sequence Analysis

The selected clones were purified and sequenced as previously described [48]. Briefly, $100 \mathrm{ml}$ PCR product generated with primers SP6 and T7 were purified with a QIAquick PCR Purification Kit (Qiagen) and sequenced with a LICOR DNA sequencer Long Read 4200 [30]. Sequencing reactions were carried out by cycle sequencing with the SequiTherme system EPICENTRE with 2 pmol fluorescently labeled primer T7 and $5 \mathrm{U}$ SequiTherm thermostable DNA polymerase. The obtained sequences were compared with known sequences by using the FASTA search option [34] for the EMBL database to search for close evolutionary relatives. Accession numbers are listed in Figs. $1 b$ and $2 b$.
Quantification of M. xanthus by Real-Time PCR

For qPCR reactions, $2 \times$ PCR Master Mix (SensiMix dT, Quantace) was diluted as recommended by the manufacturers. The specific primer pair Frz799/Frz1147 was used, and 12.5 pmol of each primer was added. SYBR Green was added at the concentration recommended by manufacturers, and PCR was carried out in $10-\mu 1$ volumes containing $2 \mu 1$ DNA as template. PCR reactions were performed using the Rotor-Gene 6000 (Corbett Research). PCR conditions: 10 -min denaturation $\left(95^{\circ} \mathrm{C}\right)$, followed by 55 cycles consisting of 1-min denaturation $\left(95^{\circ} \mathrm{C}\right)$ and 1.45 -min primer annealing and extension $\left(60^{\circ} \mathrm{C}\right)$, with a final extension step of $72^{\circ} \mathrm{C}$ for $5 \mathrm{~min}$. Fluorescent measurements were recorded during each extension step. The amplification program was immediately followed by a melt program consisting of a gradual increase from $60^{\circ} \mathrm{C}$ to $95^{\circ} \mathrm{C}$ at a rate of $0.5^{\circ} \mathrm{C}$ with intervals of $10 \mathrm{~s}$. The Rotor Gene 6 software (Corbett Research) was used to establish $C_{\mathrm{t}}$ values for each sample.

The efficiency of the assay was determined by performing the standard curve on the basis of tenfold serial dilutions of $M$. xanthus DNA in the range of $600 \mathrm{ng}$ to $60 \mathrm{fg}$ per PCR reaction. These DNA concentrations are equivalent to $3.9 \times$ $10^{7}$ to 3.9 bacteria, if estimated that approx. 10.4 fg of DNA by a genome size of 9,454 kbp [7] corresponds to one bacterium. Vegetatively growing cells of $M$. xanthus contain one to two copies of the genome, but upon entry into stationary phase, the chromosome copy number drops to a single copy. Of particular interest, fruiting body-derived myxospores contain a specific two-chromosome DNA complement with both origin and terminus regions localized to the periphery of the myxospore [54]. This means that each bacterium contains in average 1.5 genomes [54], and this would correspond to approx. 15.5 fg of DNA per bacterium. Each standard was quantified in triplicate.

For the quantification of $M$. xanthus DNA on treated samples, $2 \mu 1$ out of $100 \mu 1$ undiluted DNA extracts were added to each PCR reaction as template DNA. The $100 \mu \mathrm{l}$ DNA were extracted from the $2 \mathrm{ml}$ sample collected from each Erlenmeyer at different times, as mentioned above. This information allows us to calculate the concentration of DNA per milliliter of sample and hence, the number of $M$. xanthus cells per milliliter of sample.

\section{Results}

PCR-DGGE Analysis of the Microbiota-Inhabiting Non-treated and Treated Calcarenite Stones

The microbiota inhabiting quarry and decayed ornamental calcarenites were investigated by PCR-DGGE analysis. Two different primer pairs, 341f/907r and 341f/1492r 
Figure 1 PCR-DGGE profiles representing the succession in the bacterial community structure, as well as the monitoring during the time course experiment of $M$. xanthus on quarry calcarenite. DNA was directly extracted from non-treated $(Q)$ and treated $(T Q)$ stone slabs, as well as from aliquots taken from the culture medium of treated samples during the time course experiment, and subsequently amplified with the $16 \mathrm{~S}$ rRNA primers pair 341f/907r. Numbers of lanes indicate sampling days. Lane $M$, marker of M. xanthus. DGGE-bands identified from the $16 \mathrm{~S}$ rDNA clone libraries are numbered and are indicated by arrowheads. These bands are described in the b. Closest relative, as determined by comparative sequence analysis, level of identity with this relative, clone designation, and accession number for each band are summarized in $\mathbf{b}$ a Day

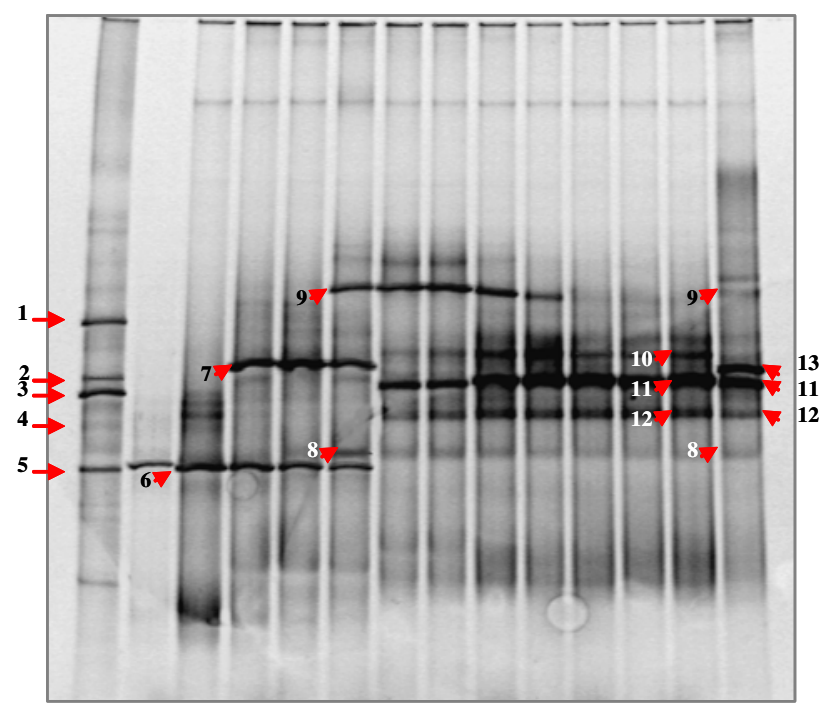

Q: non-treated quarry stone / TQ: treated quarry stone after 30 days of treatment

b

\begin{tabular}{|c|c|c|c|c|}
\hline $\begin{array}{l}\text { DGGE } \\
\text { Band }\end{array}$ & $\begin{array}{l}\text { Closest identified phylogenetic relatives } \\
\text { (EMBL accession numbers) }\end{array}$ & $\underset{\%}{\operatorname{Similarity}}$ & Clones & $\begin{array}{l}\text { Accession } \\
n^{\circ}\end{array}$ \\
\hline 1 & Diaphorobacter sp [AB076855; AB076856; AB064317] & 99.5 & CLA-K13 & AM940953 \\
\hline 2 & $\begin{array}{l}\text { Acidovorax sp. [DQ111771], [AJ534865], [AM084034; } \\
\text { AM084010] }\end{array}$ & 99.3 & CLA-K8 & AM940952 \\
\hline 3 & Imtechium assamiensis sp [AY544767] & 95.7 & CLA-K7 & AM940951 \\
\hline 4 & $\begin{array}{l}\text { Comamonas aquatica sp.[AJ430345; AJ430346; } \\
\text { DQ187385] }\end{array}$ & 99.6 & CLA-K24 & AM940954 \\
\hline 5 & Sphingomonas sp. [AF411072] & 97.8 & CLA-K4 & AM940949 \\
\hline 6 & Myxococcus xanthus [CP000113] & 100 & CL1.3-K6 & FM882256 \\
\hline 7 & $\begin{array}{l}\text { Bacillus sp. [AE017355], [CP000001], [AE016877], } \\
\text { [AE016879], [AE017334] }\end{array}$ & 99.7 & CL1.3-K10 & AM947006 \\
\hline 8 & Pseudomonas sp. [AF063219], [AF067960], [EF198403]. & 94.8 & CL1.3-K4 & AM947007 \\
\hline 9 & $\begin{array}{l}\text { Pseudomonas sp. [AY017341], [AJ312172], [AJ312173], } \\
\text { [AJ312174], [AY683883], [AY683884], [EF025737]. }\end{array}$ & 99.8 & CL1.3-K17 & AM947008 \\
\hline 10 & $\begin{array}{l}\text { Low } \mathrm{G}+C \text { Gram-positive bacterium D-N(1)-3C [AB074677] } \\
\text { Brevibacillus sp. [AY591911], [AB112712] }\end{array}$ & $\begin{array}{l}99.5 \\
99.3\end{array}$ & CL2L-K7 & AM940960 \\
\hline 11 & $\begin{array}{l}\text { Brevibacillus } s p \text {. [AY591911], [AB112712] [AF378234] } \\
\text { Low G+C Gram-positive bacterium D-N(1)-3C [AB074677] }\end{array}$ & $\begin{array}{l}99.5 \\
99.5\end{array}$ & CL2S-K14 & AM949681 \\
\hline 12 & $\begin{array}{l}\text { Brevibacillus } s p \text {. [AF378234] } \\
\text { Low } \mathrm{G}+C \text { Gram-positive bacterium D-N(1)-3C [AB074677] }\end{array}$ & $\begin{array}{l}99.7 \\
99.3\end{array}$ & CL2S-K6 & AM949679 \\
\hline 13 & Bacillus licheniformis sp. [AE017333], [CP000002] & 99.3 & CL2S-K8 & AM949680 \\
\hline
\end{tabular}

(see section of "Methods") were used to amplify the $16 \mathrm{~S}$ rRNA gene. DNA could be successfully amplified from all stone samples by using both primer combinations, resulting in nearly identical DGGE fingerprints (data not shown), indicating the reproducibility of the method. However, the amplification of DNA using primers pair $341 \mathrm{f} / 907 \mathrm{r}$ allowed a better visualization of faint bands on each sample, and therefore, this primer combination was used in further PCR-DGGE analysis.

A) Quarry stone

DGGE fingerprints derived from non-treated (Q) and treated (TQ) quarry calcarenite are shown in Fig. 1. The profiles showed a low number of dominant bands, 
Figure 2 PCR-DGGE profiles representing the succession in the bacterial community structure, as well as the monitoring during the time course experiment of $M$. xanthus on decayed calcarenite. DNA was directly extracted from non-treated $(D)$ and treated $(T D)$ stone slabs, as well as from aliquots taken from the culture medium of treated samples during the time course experiment, and subsequently amplified with the 16S rRNA primers pair 341f/907r. The description for lane numbers and for $\mathbf{b}$ are as indicated for Fig. 1 a Day D M $\overline{0} \begin{array}{lllll}1 & 2 & 3 & 6 & 810152025 \text { 30TD }\end{array}$

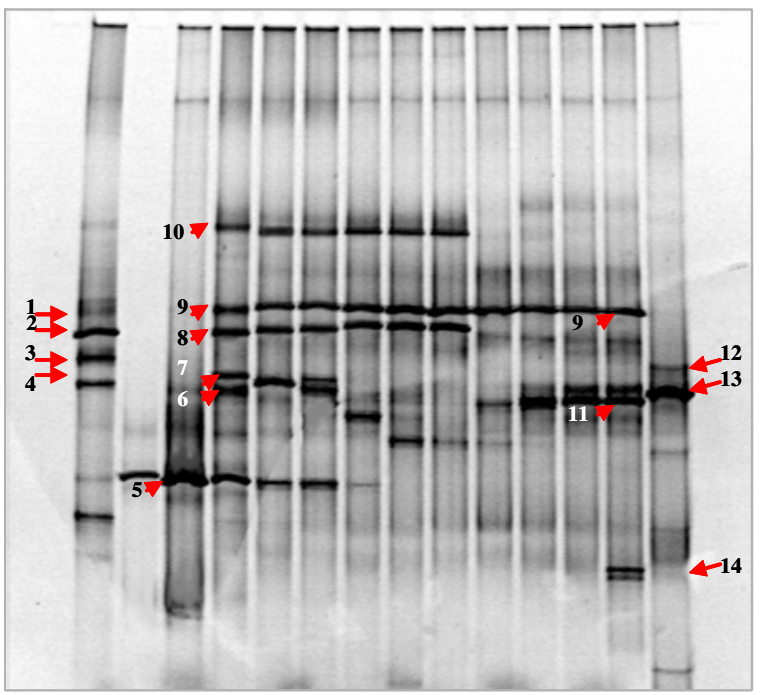

D: non-treated decayed stone /TD: treated decayed stone after 30 days of treatment

b

\begin{tabular}{|c|c|c|c|c|}
\hline $\begin{array}{l}\text { DGGE } \\
\text { Band }\end{array}$ & $\begin{array}{l}\text { Closest identified phylogenetic relatives } \\
\text { (EMBL accession numbers) }\end{array}$ & $\underset{\%}{\text { Similarity }}$ & Clones & $\begin{array}{l}\text { Accession } \\
n^{\circ}\end{array}$ \\
\hline 1 & Acinetobacter junii [AB101444], [AY881242] & 99.6 & CLB-K4 & AM940955 \\
\hline 2 & Acinetobacter junii [AB101444] & 99.1 & CLB-K22 & AM940958 \\
\hline 3 & $\begin{array}{l}\text { Acinetobacter sp [X81659], [DQ837531], [AM401576], } \\
\text { [EF111219] }\end{array}$ & 95.0 & CLB-K7 & AM940956 \\
\hline 4 & Imtechium assamiensis [AY544767] & 99.3 & CLB-K18 & AM940957 \\
\hline 5 & Myxococcus xanthus [CP000113] & 100 & CL2.3-K5 & FM882257 \\
\hline 6 & Pseudomonas stutzeri [U65012], [U65012] & 97.6 & CL2.3-K12 & AM947009 \\
\hline 7 & Naxibacter varians [AM774587] & 98.8 & CL2.3-K19 & AM947010 \\
\hline 8 & Pseudomonas stutzeri [AF063219], [AF067960] & 99.5 & CL2.3-KJ & AM947011 \\
\hline 9 & $\begin{array}{l}\text { Pseudomonas sp. [AY017341], [AJ312172], [AJ312173], } \\
\text { [AJ312174], [AY683883], [AY683884], [EF025737]. }\end{array}$ & 99.8 & CL2.3-K13 & AM947012 \\
\hline 10 & Pseudomonas stutzeri [AF063219], [AF067960]. & 99.8 & CL2.3-LK7 & AM947013 \\
\hline 11 & $\begin{array}{l}\text { Brevibacillus sp. [AF378230]; [AB215102]; [AB112721]; } \\
\text { [AB116134]; [AJ586382]; [EF139656]; [DQ350827], } \\
\text { [AF252328] }\end{array}$ & 99.6 & CL16L-K9 & AM940970 \\
\hline 12 & Bacillus silvestris sp. [AJ006086] [EU249562] & 99.3 & CL16S-K9 & AM949683 \\
\hline 13 & Bacillus silvestris sp. [AJ006086] [EU249562] & 99.3 & CL16S-K13 & AM949684 \\
\hline 14 & Exiguobacterium sp. [DQ530521], [DQ019166] & 98.5 & CL16S-K7 & AM949682 \\
\hline
\end{tabular}

representing the diversity of the $16 \mathrm{~S}$ rDNA sequences due to different bacterial types. Five different dominant bands were visible on the profile of non-treated stone (lane Q, bands 1-5), and after 30 days of treatment, the profile derived from the treated quarry stone revealed the dominance of only three bands (lane TQ, bands 11-13).

To obtain detailed phylogenetic information about the members of the community inhabiting non-treated and treated quarry calcarenite, the stone slab samples Q and TQ were used for the construction of clone libraries. Sequence results obtained from inserted clones showed percent sequence similarities between $94.8 \%$ and $100 \%$ with sequences from the EMBL (see Fig. 1b).

Sequences of clones derived from non-treated quarry stone $(\mathrm{Q})$ corresponding to DGGE-bands 1-4 were phylogenetically affiliated with genera of the cultivated $\beta$ - 
Proteobacteria, namely Diaphorobacter, Acidovorax, Imtechium, and Comamonas, respectively. Sequence corresponding to DGGE-band 5 was phylogenetically affiliated with a cultivated genus of the $\alpha$-Proteobacteria, namely Sphingomonas.

Fingerprint derived from treated quarry calcarenite (TQ) showed three dominant bands, DGGE-bands 11 and 12 related to species of genus Brevibacillus and DGGE-band 13 related to Bacillus sp. In addition, two faint bands (DGGE-bands 8 and 9), corresponding to Pseudomonas sp., could be also detected inhabiting the stone slab.

\section{B) Decayed stone}

DGGE fingerprints derived from non-treated (D) and treated (TD) decayed calcarenite are shown in Fig. 2. As for quarry calcarenite, the profile derived from non-treated decayed stone showed four to five different dominant bands (lane D, bands 1-4). DGGE profile of treated decayed stone showed only two dominant bands (lane TD, bands 12 and 13) and few faint bands (as band 14).

Clone libraries derived from stone slab samples D and TD allowed the phylogenetic identification of the community members inhabiting the stone. Comparative sequence analysis showed percent sequence similarities between $95 \%$ and $100 \%$ with sequences from the EMBL (see Fig. 2b).

Cloned sequences derived from sample D corresponding to DGGE-bands 1-3 were phylogenetically affiliated with genera of the cultivated $\gamma$-Proteobacteria Moraxellaceae, of the genus Acinetobacter. Clone corresponding to DGGEband 4 was phylogenetically affiliated with a cultivated $\beta$ Proteobacteria of the genus Imtechium. Furthermore, a fifth additional band was observed at the bottom of the fingerprint of sample D (see Fig. 2). However, this DGGE-band could not be further characterized, even after several cloning attempts. Additional efforts to get this band by cutting it out of the gel yielded no results by directly sequencing.

After 30 days of treatment, the DGGE-fingerprint derived from the stone slab sample TD showed two dominant bands (bands 12 and 13) both phylogenetically related to Bacillus sp. In addition, it was possible to detect a faint band (band 14), also visible at the supernatant sample of day 30, related to the genus Exiguobacterium.

Bacterial Community Dynamics During the Treatment of Calcarenites with a $M$. xanthus-Inoculated Culture Medium

\section{A) Quarry stone}

Figure 1 shows the original DGGE fingerprints obtained from aliquots taken from the Erlenmeyer flasks over the time course experiment (30 days). As expected, immediately after the application of the $M$. xanthus-inoculated culture (lane 0), a unique dominant band was observed (DGGE-band 6) corresponding to M. xanthus. From the first day on, it was possible to see the appearance of dominant DGGE-bands, such as band 7, corresponding to Bacillus sp. which dominated the first 3 days of the experiment. At this time, DGGE-bands 8 and 9, both corresponding to Pseudomonas sp., appeared. The intensity of the bands 8 and 9 decreased during the time course experiment, while three other bands gradually showed up (DGGE-bands 10-12) corresponding to Brevibacillus sp.

\section{B) Decayed stone}

Regarding decayed stone, a similar behavior was observed with respect to the succession of the microbial community during the application of the M. xanthusinoculated culture (Fig. 2). Immediately after the application of the treatment (lane 0), a unique dominant band was observed (DGGE-band 5) corresponding to M. xanthus. The DGGE profile from the first day of the experiment (lane 1) showed the appearance of five additional dominant bands. DGGE-bands 6, 8-10 corresponded to sequences of Pseudomonas sp., and DGGE-band 7 to Naxibacter varians. These bands were stable until the third day of the experiment. During the 6th and 15th day, DGGE profiles showed a shift in the microbial community and some bands disappeared. Then after, two DGGE bands (bands 9 and 11) corresponding to Pseudomonas sp. and Brevibacillus sp., respectively, dominated until the end of the experiment.

\section{Monitoring and Quantification of $M$. xanthus During} the 30 Days of Treatment

To monitor the dynamic followed by the inoculated bacterium, M. xanthus, as well as the potential competition between this strain and those activated from the stone during the treatment, different methods were applied and compared.

Culture-dependent assays yielded positive results only from aliquots taken from the culture medium the first day of the treatment, showing a limitation of these conventional techniques. Therefore, culture-independent methods were chosen for the monitoring of M. xanthus. Three different molecular approaches were used, as described below.

First, PCR-DGGE analysis of amplified $16 \mathrm{~S}$ rDNA directly extracted from aliquots of treated samples, using universal bacterial primers. DNA of $M$. xanthus was loaded on the gel as marker (lane $M$ of Figs. 1 and 2). DGGE profiles showed the presence of $M$. xanthus in quarry calcarenite samples during the first 3 days of treatment (DGGE-band 6 Fig. 1) and in the decayed calcarenite samples during the first 6 days of treatment (DGGE-band 5 
Fig. 2). Afterwards, it was not possible to visualize a DGGE-band corresponding to the DNA of $M$. xanthus in the fingerprints of the treated samples.

To overcome this problem, a second molecular approach was developed to increase the sensitivity in the level of detection of M. xanthus based on the use of species-specific primers. For this purpose, the frz locus of M. xanthus was selected as target sequence to be amplified, and the specific primer pair Frz799/Frz1147 was designed, which amplifies $349 \mathrm{bp}$ of the frzABCD gene. To test the specificity of the primer pair Frz799/Frz1147, a PCR was set up using as template DNA from $M$. xanthus as well as from other different bacterial taxons (see section of "Methods"). Only the DNA of $M$. xanthus could be amplified using this primer combination, indicating the specificity of primers Frz799/Frz1147. Furthermore, stone slabs and aliquots of samples treated during 30 days with culture medium inoculated and non-inoculated with M. xanthus (see section of "Methods") were tested by PCR analysis using the specific primer pair Frz799/Frz1147 for the presence/ absence of $M$. xanthus. Samples treated with a culture medium non-inoculated with $M$. xanthus (acting as a control) showed no amplification of the DNA extracted from either the stone slab or the culture medium, demonstrating the specificity of the primers. Nevertheless, the DNA extracted from the culture medium of samples inoculated with M. xanthus could be amplified by using this specific primer pair throughout the experiment (30 days). However, it is worth noting that the amplification of the DNA extracted from stone slabs treated with a M. xanthusinoculated culture was not possible.

The third molecular approach was the quantification of the DNA of $M$. xanthus in the treated samples during the time course experiment by qPCR. The specific primers pair Frz799/Frz1147 was used, and the efficiency of the assay was determined by performing the standard curve on the basis of tenfold serial dilutions of $M$. xanthus, as mentioned in section of "Methods". In a range between $600 \mathrm{ng}$ and $60 \mathrm{fg}$, a slope of -3.3 was obtained in the standard curve, indicating an efficiency of $0.99 \%$ and a $R^{2}$ of 0.99 . $C_{\mathrm{t}}$ values were inconsistent at a DNA concentration under $60 \mathrm{fg}$ per reaction.

Optimization tests for qPCR were performed with the prepared serial dilutions of purified M. xanthus DNA. Different concentrations of $\mathrm{MgCl}_{2}$ (ranging from 3 to $5 \mathrm{mM}$ ) and of primers (ranging from 12.5 to $1.25 \mathrm{pmol}$ ) were tested. Results showed no significant differences when using different concentrations of $\mathrm{MgCl}_{2}$. However, the concentration of primers showed to be a critical point, the lower the primers concentration, the higher the $C_{\mathrm{t}}$ values, indicating a delay to reach the minimum number of PCR cycles needed to obtain significant fluorescence signals. Consequently, the higher concentration of primer
(12.5 pmol) and the lower concentration of $\mathrm{MgCl} 2(3 \mathrm{mM})$ tested were kept for the further analyses of samples.

The $C_{\mathrm{t}}$ values of reactions derived from treated samples throughout the experiment, as well as the related DNA concentration determined in qPCR are given in Table 1. Since samples were run in duplicate, each value represents the average of two individual reactions.

Our results show that the concentration of $M$. xanthus DNA in the treated quarry and decayed stone samples immediately after the immersion of the slabs in the inoculated culture medium were 2,580 and 2,701 $\mathrm{ng} \mathrm{ml}^{-1}$ sample, corresponding to $1.6 \times 10^{8}$ and $1.7 \times 10^{8}$ cells ml $^{-1}$ sample, respectively. After 3 days of treatment, the $M$. xanthus DNA concentration decreased strongly in the culture medium of treated quarry stone (from $617 \mathrm{ng} \mathrm{ml}^{-1}$ sample at day 3 to $1 \mathrm{ng} \mathrm{ml}^{-1}$ sample at day 6), what is in accordance with the results obtained with DGGE analysis, where no DGGE-band corresponding to $M$. xanthus was detected after the third day of treatment (see Fig. 1). In the culture medium of treated decayed stone, the DNA concentration decreased gradually between days 3-6 of the experiment (from $545 \mathrm{ng} \mathrm{ml}^{-1}$ sample at day 3 to $58 \mathrm{ng} \mathrm{ml}^{-1}$ sample at day 6), which is also in accordance with the results obtained with DGGE analysis, where it was still possible to detect a faint band corresponding to $M$. xanthus at the sixth day of treatment (see Fig. 2). At the end of the treatment (30 days), it was possible to detect $0.37 \mathrm{ng}$ DNA of $M$. xanthus per milliliter sample of both treated quarry and decayed stones (Table 1 ), what is equivalent to $2.2 \times 10^{4}$ cells per milliliter sample.

\section{Discussion}

In a previous investigation to this study, Jimenez-Lopez et al. $[18,19]$ developed a consolidation treatment for ornamental stones based on the application of a sterile specific culture medium or a medium inoculated with $M$. xanthus, as calcium carbonate-precipitating bacteria. Both treatments succeed in the activation of bacteria inhabiting the stones, with a potential for calcium carbonate precipitation. Nevertheless, the effects of the application of a culture medium to a stone that has its own microbiota, as well as the effects of the introduction of a new strain on such community, have been to date not clarified. Therefore, as follow-up of the studies mentioned above, in this work, we investigated and compared the microbiota-inhabiting quarry and decayed ornamental carbonate stones before and after the application of a culture medium inoculated with $M$. xanthus as stone consolidation treatment. Furthermore, the bacterial community dynamics during the application of such a treatment, as well as the prevalence of the inoculated strain, M. xanthus, were monitored by using a molecular strategy. 
Table 1 Quantification by realtime PCR of $M$. xanthus DNA on the culture media used for the treatment of quarry and decayed ornamental stone slabs during 30 days

$Q$ quarry stone, $D$ decayed stone
${ }^{\text {Mean }}$ values of two individual
reactions/standard deviation ( $n=2)$

Identification of the Microbiota-Inhabiting Non-treated and Treated Stones

Comparing the detected autochthonous microbiota of nontreated quarry and decayed calcarenites, species belonging to the $\beta$-Proteobacteria dominated on quarry calcarenite while $\gamma$-Proteobacteria dominated on decayed calcarenite. In summary, sequences derived from the non-treated quarry calcarenite (Q) were related to cultivated members of the $\beta$-Proteobacteria, family Comamonadaceae, namely Diaphorobacter [17, 21, 22], Acidovorax [16], and Comamonas [57]. These sequences were also phylogenetically affiliated with uncultured bacterial clones found in ground waters from a deep mine [27] and activated sludge [21]. Sequence corresponding to DGGE-band 3 was phylogenetically affiliated with Imtechium assamiensis strain BPTSA16, isolated from a warm spring of Assam in India (not validly published). This clone showed also similarities with different uncultured bacterial clones related with degradation process [50], benzene- and monochlorobenzene-contaminated ground water [1], and activated sludge [56]. Sequence corresponding to DGGE-band 5 was phylogenetically affiliated with the $\alpha$-Proteobacteria, family Sphingomonadaceae, namely Sphingomonas, as well as with an uncultured bacterium clone associated with a Geological Substrata in a Pristine Aquifer [5]. In general, these environments are consistent with the geological/hydrological setting of the quarry from which the carbonate stone was extracted $[18,19]$.

Furthermore, sequences derived from the non-treated decayed calcarenite (D) revealed high similarities with the cultivated $\gamma$-Proteobacteria Moraxellaceae of the genus Acinetobacter [29, 37]. Some of the sequences related to Acinetobacter sp. showed phenanthrene-degrading activities [4]. Clone corresponding to DGGE-band 4 was phylogenetically affiliated with the genus Imtechium, as well as with different uncultured bacterial clones involved in degradation process $[1,56]$. These results are consistent with the origin as well as the exposure of the decayed calcarenite to urban contaminants.

It is worth noting the presence of I. assamiensis in the microbiota colonizing both non-treated calcarenites. As mentioned above, this bacterium was isolated from a warm spring. This habitat is more in accordance with the physico-chemical environment of the quarry calcarenite, suggesting that the presence of this bacterium in the decayed stone is a remnant of the quarry from which the stone was once collected.

After 30 days of treatment, sequences derived from the treated quarry (TQ) calcarenite were related to species of genus Brevibacillus, Bacillus [14, 28], and Pseudomonas [40]. Sequences derived from the treated decayed (TD) calcarenite were related to species of genus Bacillus. In addition, weak bands corresponding to Brevibacillus and 
Exiguobacterium [41] genera were detected on the stone slab. These results indicate that these few bacterial genera were the fraction of the total bacterial community optimally activated during the treatment and able to dominate on the treated stone, thus being detectable by PCR-DGGE [31]. As demonstrated by Jimenez-Lopez et al. $[18,19]$, all activated bacteria, once isolated on solid M3-P culture medium, were able to produce considerable amount of calcium carbonate. This observation is in agreement with the results from other authors regarding the potential for calcium carbonate precipitation of some species of Bacillus and Pseudomonas genera as B. sphaericus [15], B. cereus [6], B. thuringiensis, and B. pumilus [3], P. halophila [39] and P. fluorescens [2].

Bacterial Community Dynamics During the Incubation of the Stone Slabs with a M. xanthus-Inoculated Culture

The bacterial community dynamics in the culture media of both quarry and decayed calcarenites, showed in Figs. 1 and 2 indicated the activation of very specific groups of organisms throughout the treatment. DGGE fingerprints derived from the quarry calcarenite culture (Fig. 1) showed a bacterial succession, where species belonging to Bacillus were quickly activated by the application of the culture medium and dominated during the first 3 days of the experiment. Afterwards, an activation of Pseudomonas sp. inhibited the further proliferation of Bacillus sp., and this species dominated during the days $3-15$ of the experiment. Finally, from day 6 on, species belonging to Brevibacillus were activated and dominated until the end of the experiment. The proliferation of Brevibacillus sp. produced a gradual disappearance of Pseudomonas sp. These results suggest an antagonistic behavior among the bacteria activated, probably triggered by the lack of nutrients. However, a more detailed study, which is beyond the scope of the present one, would be needed to prove the causes of such an antagonism. In fact, it has been shown that Pseudomonas is able to produce membrane vesicles (MVs) filled with periplasmic components with a predatory role in natural ecosystems [20]. MVs are capable of lysing a variety of Gram-negative and Gram-positive bacteria, as Bacillus sp. [20], increasing the availability of nutrients. In addition, there are works reporting that sporulating bacteria develop predation behaviors in mixed cultures under nutritional stress, by using an antibacterial factor [23]. This fact could explain the observation of the gradual disappearance of Pseudomonas sp. when Brevibacillus sp. proliferated in the medium.

Similarly, DGGE fingerprints showed a bacterial succession during the time course experiment when a culture of M. xanthus was applied to decayed calcarenite (Fig. 2). In this case, Pseudomonas sp. dominated during the first
15 days of the experiment. At this time, the activation of Brevibacillus sp. and Bacillus sp. induced a shift in the population of Pseudomonas sp., and those sporulating bacteria dominated until the end of the experiment. This phenomenon could be also explained by the predation behavior of sporulating bacteria under nutrient stress mentioned above [23].

An interesting finding is that, irrespective of the origin of the stone (quarry versus decayed), the same microorganisms were activated by the application of a M. xanthusinoculated culture for consolidating the stone. Those microorganisms were Pseudomonas sp., Bacillus sp., and Brevibacillus sp. These bacteria are commonly found in natural environments and have also been found in ornamental rocks from different locations [55]. They are aerobic chemoorganotrophs and can grow in culture media containing amino acids and within the $\mathrm{pH}$ ranges and temperature of our experiments. Some of them were spore-forming bacteria, as Brevibacillus sp. and Bacillus sp. [49, 51]. Pseudomonas sp. produces extracellular polysaccharides which provide protection against a variety of environmental stresses, such as UV radiation, $\mathrm{pH}$ shifts, osmotic shock, and desiccation [40]. These characteristics could explain why the latter strains were activated and detected either due to their ability to form spores or to produce extracellular polysaccharides and, therefore, to their resistance to dry conditions on the stones.

Comparison Among the Bacteria Detected in the Culture Medium During the Application of a M. xanthus Culture and the Bacteria Colonizing the Stone

Comparing the bacteria detected in the culture medium with those detected in the stone, it is worth noting that the bacteria detected in the non-treated stone were not detected in the culture medium and vice versa.

The first observation can be explained by the fact that the identified non spore-forming bacteria, detected in nontreated stones, could enter into dormant stages and were not reactivated by the provided culture media, since it has already been reported that dormant microorganisms are unable to grow on standard culture media [45]. Therefore, bacteria detected on the non-treated stone were probably non-activated, or although activated, those bacteria may not be abundant enough to be detected by the electrophoretic techniques used in this study [31].

Regarding the second observation, bacteria detected in the culture medium could be non-detected in the stone for several reasons. One thereof is that spore-forming bacteria, as the detected Bacillus and Brevibacillus, could be initially in the non-treated stone and later activated by the culture medium. In this case, those bacteria may not be detected in the stone due to some limitations of molecular techniques. 
In fact, several works reported on bias for the extraction of DNA from spores [24, 25] and on the preferential amplification of some sequences, excluding Bacillus-16S rDNA $[10,38]$. This could explain why these bacteria were not detected in the non-treated stone but were detected later on in the culture medium.

Finally, some bacteria present in the culture medium were not detected in the stone after the treatment. This can be explained by the calcification of the bacteria into the stone, as showed by Jimenez-Lopez et al. [18, 19], thus preventing the extraction of DNA. In this regard, it is important to consider the case of Pseudomonas, which was detected in the culture medium of decayed calcarenite (see Fig. 2), but not in the decayed stone neither in non-treated or treated ones. It is known that Pseudomonas is very active in inducing the precipitation of calcium carbonate [3]; thus, most Pseudomonas cells present in the stone may be calcified, leaving not enough population to be detected by molecular techniques [31]. Furthermore, there are works showing difficulties in DNA extraction due to the strong binding of DNA to certain mineral surfaces $[9,44]$.

\section{Monitoring and Quantification of M.xanthus During the Time Course Experiment}

Our results highlight the limitations of culture-dependent techniques for the monitoring of $M$. xanthus in a mixed culture, which yielded positive results only the first day of the treatment. This fact can be related to the greater generation time of $M$. xanthus compared to that of the other activated bacteria [19]. Once those bacteria become activated, their growth overlaps that of M. xanthus, hindering its detection by cultivation techniques. To overcome this problem, we used molecular techniques to monitor the inoculated strain, M. xanthus. However, some limitations were detected by using PCR-DGGE analysis, even if this technique has been successfully applied for the analysis of microbial communities on monuments and building materials $[11,35,36]$. Therefore, specific primers were designed in this study to amplify the DNA of $M$. xanthus, which allow the detection of the targeted microorganism, even if there are differences in the relative abundance avoiding competition during PCR. The primer pair Frz799/Frz1147 was selected, which amplifies 349 bp of the frzABCD gene. By using this specific primer pair, we succeed in the detection and quantification of $M$. xanthus in the culture medium of samples treated with this bacterium during the time course experiment (30 days). Our qPCR analysis showed to be reliable, with a standard curve having a correlation coefficient $R^{2}$ value of 0.99 and a slope of -3.3 . These values are inside the recommended limits [58]. Furthermore, results derived from qPCR analysis correlated well to those derived from PCR-
DGGE analysis. DGGE profiles showed that, under the conditions given in our experiments, the detection of $M$. xanthus in a mixed culture was not possible by this fingerprinting technique after the first 3-6 days of the experiment (for quarry and decayed stone, respectively). At this time, the population of this bacterium was below $10^{6}$ bacteria per milliliter of sample (see Table 1). The limitation of PCR-DGGE analyses can be explained by the several factors affecting the quantities of PCR products obtained for fingerprinting techniques when using universal primers as, i.e., the differential or preferential amplification of rRNA genes by PCR [38], differences in the genome size and the copy number of 16SrRNA genes [10], and the relative abundance of the target sequence in the total microbial community [31]. The qPCR performed with the specific primers for $M$. xanthus showed to be a very sensitive technique for the detection of this bacterium in a mixed culture, revealing a population of $10^{4}$ cells ml ${ }^{-1}$ in the culture media of both treated stones at the end of the consolidation treatment. However, the amplification of the DNA of $M$. xanthus from the stone slabs was not possible after the 30 days of treatment, even by using the specific primer pair. This can be explained by the calcification of $M$. xanthus into the stone $[18,19]$, preventing the extraction of DNA from this bacterium

\section{Relevance of the Present Study for the Optimization} of the Consolidation Treatment

Results obtained in this work provide new data to optimize the consolidation method for both decayed and quarry calcarenite, based on the application of a culture medium inoculated with $M$. xanthus, already described [18, 19, 42]. In these previous studies, authors observed that a $\mathrm{pH}$ increase and calcium consumption from the culture media occurred due to the bacterial metabolic activity, mainly within the 15 first days of the experiment. Calcium carbonate precipitation occurred earlier and was more noticeable in those experiments inoculated with $M$. xanthus $[18,19]$. This fact showed that the presence of M. xanthus accelerates the production of new calcium compared to the M. xanthus-free experiments, since the achievement of the necessary super-saturating conditions for calcium carbonate precipitation in the latter experiments was delayed until the microbial community inhabiting the stone was activated.

Taking together the data mentioned above with the results obtained in this study, our DGGE fingerprints showed that the microbiota activated within the first stages of the treatment was dominated by Bacillus sp. and Pseudomonas sp. in the case of quarry calcarenite (Fig. 1) and by Pseudomonas sp. in the case of decayed calcarenite (Fig. 2). Therefore, those bacteria, along with M. xanthus are probably responsible for the consolidation achieved in 
the treated stone within the first week. Furthermore, our qPCR analyses showed that the population of M. xanthus during the first 3 days of the experiment varied between $10^{8}$ and $10^{7}$ bacteria per milliliter, indicating that this bacterium would be the main responsible for the precipitation of calcium carbonate within the first hours-days, until Pseudomonas sp. and Bacillus sp. become activated by the culture medium. It is not clear, however, the role of Brevibacillus sp. on the precipitation of calcium carbonate at the later stages of the experiment (last 15 days). The almost absence of calcium in the culture medium at these time intervals may have prevented further calcium carbonate precipitation by Brevibacillus sp., since the saturation of the system with respect to calcite was very close to equilibrium [19]. This data is important, since it demonstrates that even though other bacteria may be activated as a result of the consolidation treatment, an uncontrolled calcium carbonate precipitation, which could be potentially problematic, does not occur, since such a precipitation is limited by the calcium concentration in the culture medium used for the treatment.

Based on these results, it seems clear that the decisive time frame for the conservation treatment is the first 7 days. Therefore, the treatment proposed by Rodriguez-Navarro et al. [42] and Jimenez-Lopez et al. [18, 19] to consolidate ornamental carbonated stones may be optimized by significantly reducing the time of the treatment, which also reduces noticeably the costs.

\section{Conclusions}

In summary, this study highlights the advantages of the application of a molecular strategy to monitor the microbial community dynamics occurring when a restoration treatment, based on the use of a culture medium inoculated with M. xanthus as biomineralization agent, is applied to protect and consolidate ornamental stones.

The molecular strategy used in this study allows to monitor the dynamics of the natural microbial community present on the stones, as well as the inoculated strain, M. xanthus, during the time course of the consolidation treatment. Results reveal that the culture medium used in this study activates the same group of calcium carbonate producing bacteria, irrespectively of the origin of the stone. The earlier activated Pseudomonas and Bacillus sp. may be responsible, together with the inoculated $M$. xanthus, of the calcium carbonate precipitation during the first days of the treatment. This offers the possibility of reducing the time of the consolidation treatment to a period of a week, with the consequent reduction of costs. Furthermore, the proposed molecular strategy, together with data derived from physical and chemical analyses, may facilitate the understanding of benefits obtained from the application of a bacterially induced carbonate mineralization as restoration/conservation treatment for ornamental stones.

Acknowledgments This work was financed by grants MAT200605411 and RNM-3943 from the Spanish government (Ministerio de Educación y Ciencia) and Junta de Andalucia, respectively. The study was supported by Research Group BIO103 (Junta de Andalucía). Molecular analyses and G. Piñar were financed by the "HerthaFirnberg-Nachwuchsstelle (T137)" from FWF (Austrian Science Fund).

Open Access This article is distributed under the terms of the Creative Commons Attribution Noncommercial License which permits any noncommercial use, distribution, and reproduction in any medium, provided the original author(s) and source are credited.

\section{References}

1. Alfreider A, Vogt C, Babel W (2002) Microbial diversity in an in situ reactor system treating monochlorobenzene contaminated groundwater as revealed by $16 \mathrm{~S}$ ribosomal DNA analysis. Syst Appl Microbiol 25:232-240

2. Anderson S, Appana VD, Huang J, Viswanatha T (1992) A novel role for calcite in calcium homeostasis. FEBS Lett 308:94-96

3. Baskar S, Baskar R, Mauclaire L, McKenzie JA (2006) Microbially induced calcite precipitation in culture experiments: possible origin for stalactites in Sahastradhara caves, Dehradun, India. Curr Scienc 90:58-64

4. Bodour AA, Wang JM, Brusseau ML, Maier RM (2003) Temporal change in culturable phenanthrene degraders in response to longterm exposure to phenanthrene in a soil column system. Environ Microbiol 5:888-895

5. Boyd ES, Cummings DE, Geesey GG (2007) Mineralogy influences structure and diversity of bacterial communities associated with geological substrata in a pristine aquifer. Microb Ecol 54:170-182

6. Castanier S, Le Metayer-Levrel G, Orial G, Loubiere JF, Perthuisot JP (2000) Bacterial carbonatogenesis and applications to preservation and restoration of historic property. In: Ciferri O, Tiano P, Mastromei G (eds) Of microbes and art: the role of microbial communities in the degradation and protection of cultural heritage. Plenum, New York, pp 201-216

7. Chen H, Kuspa A, Keseler IM, Shimkets LJ (1991) Physical map of the Myxococcus xanthus chromosome. J Bacteriol 173:21092115

8. Cho K, Treuner-Lange A, O'Connor KA, Zusman DR (2000) Developmental aggregation of Myxococcus xanthus requires frgA, and $f r z$-related gene. J Bacteriol 182:6614-6621

9. Demanèche $\mathrm{S}$, Jocteur-Monrozier L, Quiquampoix $\mathrm{H}$, Simonet $\mathrm{P}$ (2001) Evaluation of biological and physical protection against nuclease degradation of clay-bound plasmid DNA. Appl Environ Microbiol 67:293-299

10. Farrelly V, Rainey FA, Stackebrandt E (1995) Effect of genome size and $r r n$ gene copy number on PCR amplification of $16 \mathrm{~S}$ rRNA genes from a mixture of bacterial species. Appl Environ Microbiol 61:2798-2801

11. González JM, Saiz-Jimenez C (2005) Application of molecular nucleic acid-based techniques for the study of microbial communities in monuments and artworks. Int Microbiol 8:189-194

12. González-Muñoz MT, Rodriguez-Navarro C, Jimenez-Lopez C, Rodriguez-Gallego M (2008) Method and product for protecting 
and reinforcing construction and ornamental materials, publication number (Spanish patent, $n^{\circ}$ P200602030, WO2008009771)

13. González-Muñoz MT (2008) Bacterial biomineralization applied to the protection-consolidation of ornamental stone: current development and perspectives. Coalition 15:12-18

14. Goto K, Fujita R, Kato Y, Asahara M, Yokota A (2004) Reclassification of Brevibacillus brevis strains NCIMB 13288 and DSM 6472 (=NRRL NRS-887) as Aneurinibacillus danicus sp. nov. and Brevibacillus limnophilus sp. nov. Int J Syst Evol Microbiol 54:419-427

15. Hammes F, Boon N, de Villiers J, Verstraete W, Siciliano SD (2003) Strain-specific ureolytic microbial calcium carbonate precipitation. Appl Environ Microbiol 69:4901-4909

16. Heylen K, Vanparys B, Wittebolle L, Verstraete W, Boon N, De Vos P (2006) Cultivation of denitrifying bacteria: optimization of isolation conditions and diversity study. Appl Environ Microbiol 72:2637-2643

17. Horiba Y, Khan ST, Hiraishi A (2005) Characterization of the microbial community and culturable denitrifying bacteria in a solid-phase-denitrification process using poly(epsilon-caprolactone) as the carbon and energy source. Microbes Environ 20:2533

18. Jimenez-Lopez C, Rodriguez-Navarro C, Piñar G, Carrillo-Rosua FJ, Rodriguez-Gallego M, Gonzalez-Muñoz MT (2007) Consolidation of degraded ornamental porous limestone stone by calcium carbonate precipitation induced by the microbiota inhabiting the stone. Chemosph 68:1929-1936

19. Jimenez-Lopez C, Jroundi F, Pascolini C, Rodriguez-Navarro C, Piñar G, Rodriguez-Gallego M, Gonzalez-Muñoz MT (2008) Consolidation of quarry calcarenite by calcium carbonate precipitation induced by bacteria activated among the microbiota that inhabits the stone. Int Biodeter Biodegr 62:352-363

20. Kadurugamuwa JL, Mayer A, Messner P, Sara M, Sleytr UB, Beveridge TJ (1998) S-layered Aneurinibacillus and Bacillus spp. are susceptible to the lytic action of Pseudomonas aeruginosa membrane vesicles. J Bacteriol 180:2306-2311

21. Khan ST, Horiba Y, Yamamoto M, Hiraishi A (2002) Members of the family Comamonadaceae as primary poly(3-hydroxybutyrateco-3-hydroxyvalerate)-degrading denitrifiers in activated sludge as revealed by a polyphasic approach. Appl Environ Microbiol 68:3206-3214

22. Khan ST, Hiraishi A (2002) Diaphorobacter nitroreducens gen. nov., sp. nov., a poly (3-hydroxybutyrate)-degrading denitrifying bacterium isolated from activated sludge. J Gen Appl Microbiol 48:299-308

23. Kumar Nandy S, Bapat PM, Venkatesh KV (2007) Sporulating bacteria prefers predation to cannibalism in mixed cultures. FEBS Lett 581:151-156

24. Kuske CR, Banton KL, Adorada DL, Stark PC, Hill KK, Jackson PJ (1998) Small-scale DNA sample preparation method for field PCR detection of microbial cells and spores in soil. Appl Environ Microbiol 64:2463-2472

25. Laiz L, Piñar G, Lubitz W, Saiz-Jimenez C (2003) Monitoring the colonisation of monuments by bacteria: cultivation versus molecular methods. Environ Microbiol 5:72-74

26. Lane DJ (1991) 16S/23S rRNA sequencing. In: Stackebrandt E, Goodfellow M (eds) Nucleic acid techniques in bacterial systematics. Wiley, Chichester, pp 115-175

27. Lin LH, Hall J, Onstott TC, Gihring T, Sherwood Lollar B, Boice E, Pratt L, Lippmann-Pipke J, Bellamy RES (2006) Planktonic microbial communities associated with fracture-derived groundwater in a deep gold mine of South Africa. Geomicrobiol J 23:475-497

28. Logan NA, Forsyth G, Lebbe L, Goris J, Heyndrickx M, Balcaen A, Verhelst A, Falsen E, Ljungh A, Hansson HB, De Vos P (2002) Polyphasic identification of Bacillus and Brevibacillus strains from clinical, dairy and industrial specimens and proposal of Brevibacillus invocatus sp. nov. Int J Syst Evol Microbiol 52:953966

29. Malik A, Sakamoto M, Hanazaki S, Osawa M, Suzuki T, Tochigi M, Kakii K (2003) Co-aggregation among non-flocculating bacteria isolated from activated sludge. Appl Environ Microbiol 69:6056-6063

30. Middendorf LR, Bruce JC, Bruce RC, Eckles RD, Grone DL, Roemer SC, Sloniker GD, Steffens DL, Sutter SL, Brumbaugh JA, Patonay G (1992) Continuous, on-line DNA sequencing using a versatile infrared laser scanner/electrophoresis apparatus. Electroph 13:487-494

31. Muyzer G, de Waal EC, Uitterlinden AG (1993) Profiling of complex microbial populations by denaturing gradient gel electrophoresis analysis of polymerase chain reaction-amplified genes coding for 16S rRNA. Appl Environ Microbiol 59:695700

32. Neefs JM, Van de Peer Y, Hendriks L, De Wachter R (1990) Compilation of small ribosomal subunit RNA sequences. Nucl Acids Res 18:2237-2317

33. Orial G, Castanier S, Le Metayer-Levrel G, Loubiere JF (1993) The biomineralization: a new process to protect calcareous stone applied to historic monuments. In: Ktoishi H, Arai T, Yamano K (ed) Proceedings of the 2nd International Conference of Biodeterioration of Cultural Property. International Communications Specialists, Tokyo, Japan, pp 98-116

34. Pearson WR (1994) Rapid and sensitive sequence comparison with FAST and FASTA. Meth Enzymol 183:63-98

35. Piñar G, Ramos C, Rölleke S, Schabereiter-Gurtner C, Vybiral D, Lubitz W, Denner EBM (2001) Detection of indigenous Halobacillus populations in damaged ancient wall paintings and building materials: molecular monitoring and cultivation. Appl Environ Microbiol 67:4891-4895

36. Piñar G, Saiz-Jimenez C, Schabereiter-Gurtner C, Blanco-Varela MT, Lubitz W, Rölleke S (2001) Archaeal communities in two disparate deteriorated ancient wall paintings: detection, identification and temporal monitoring by denaturing gradient gel electrophoresis. FEMS Microbiol Ecol 37:45-54

37. Rainey FA, Lang E, Stackebrandt E (1994) The phylogenetic structure of the genus Acinetobacter. FEMS Microbiol Lett 124:349-353

38. Reysenbach AL, Giver LJ, Wickham GS, Pace NR (1992) Differential amplification of rRNA genes by polimerase chain reaction. Appl Environ Microbiol 58:3417-3418

39. Rivadeneyra MA, Delgado R, Parraga J, Ramos-Cormenzara A, Delgado G (2006) Precipitation of minerals by 22 species of moderately halophilic bacteria in artificial marine salts media: influence of salt concentration. Folia Microbiol 51:445-453

40. Roberson EB, Firestone MK (1992) Relationship between desiccation and exopolysaccharide production in a soil Pseudomonas sp. Appl Environ Microbiol 58:1284-1291

41. Rodrigues DF, Goris J, Vishnivetskava T, Gilichinsky D, Thomashow MF, Tiedje JM (2006) Characterization of Exiguobacterium isolates from the Siberian permafrost. Description of Exiguobacterium sibiricum sp. nov. Extremoph 10:285-94

42. Rodriguez-Navarro C, Rodriguez-Gallego $\mathrm{M}$, Chekroun KB, Gonzalez-Muñoz MT (2003) Conservation of ornamental stone by Myxососcus xanthus-induced carbonate biomineralization. Appl Environ Microbiol 69:2182-2193

43. Rodriguez-Navarro C, Jimenez-Lopez C, Rodriguez-Navarro A, Gonzalez-Muñoz MT, Rodriguez-Gallego M (2007) Bacterially mediated mineralization of vaterite. Geochim Cosmochim Ac $71: 1197-1213$

44. Romanowski G, Lorenz MG, Wackernagel W (1991) Adsorption of plasmid DNA to mineral surfaces and protection against DNAse I. Appl Environ Microbiol 57:1057-1061 
45. Roszak DB, Colwell RR (1987) Survival strategies of bacteria in the natural environments. Microbiol Rev 51:365-379

46. Rozen S, Skaletsky HJ (2000) Primer3 on the WWW for general users and for biologist programmers. In: Krawetz S, Misener S (eds) Bioinformatics methods and protocols: methods in molecular biology. Humana, Totowa, pp 365-386

47. Sambrook J, Fritsch EF, Maniatis T (1989) Molecular cloning: a laboratory manual, 2nd edn. Cold Spring Harbor Laboratory, Cold Spring Harbor

48. Schabereiter-Gurtner C, Piñar G, Lubitz W, Rölleke S (2001) An advanced molecular strategy to identify bacterial communities on art objects. J Microbiol Methods 45:77-87

49. Shida O, Takagi H, Kadowaki K, Komagata K (1996) Proposal for two new genera. Brevibacillus gen. nov. and Aneurinibacillus gen. nov. Int J Syst Bacteriol 46:939-946

50. Simpson JM, Santo Domingo JW, Reasoner DJ (2004) Assessment of equine faecal contamination: the search for alternative bacterial source-tracking targets. FEMS Microbiol Ecol 47:65-75

51. Sneath PHA (1986) Endospore-forming Gram-positive rods and cocci. In: Sneath PHA, Mair NS, Sharpe ME, Holt JG (eds) Bergey's manual of systematic bacteriology, vol 2, 1st edn. Williams and Wilkins, Baltimore, p 1110

52. Teske A, Wawer C, Muyzer G, Ramsing NB (1996) Distribution of sulphate-reducing bacteria in a stratified fjord (Mariager Fjord,
Denmark) as evaluated by most-probable-number counts and DGGE of PCR-amplified ribosomal DNA fragments. Appl Environ Microbiol 62:1405-1415

53. Tiano P, Biagiotti L, Mastromei G (1999) Bacterial bio-mediated calcite precipitation for monumental stones conservation: methods of evaluation. J Microbiol Meth 36:139-145

54. Tzeng L, Singer M (2005) DNA replication during sporulation in Myxococcus xanthus fruiting bodies. Proc Natl Acad Sci USA 102:14428-14433

55. Urzi C, Garcia-Valles M, Vendrell M, Pernice A (1999) Biomineralization processes on rock and monument surfaces observed in field and laboratory conditions. Geomicrobiol J 16:39-54

56. Wagner AM, Cloete ET (2002) 16S rRNA sequence analysis of bacteria present in foaming activated sludge. Syst Appl Microbiol 25:434-439

57. Wauters G, De Baere T, Willems A, Falsen E, Vaneechoutte M (2003) Description of Comamonas aquatica comb. nov. and Comamonas kerstersii sp. nov. for two subgroups of Comamonas terrigena and emended description of Comamonas terrigena. Int $\mathrm{J}$ Syst Evol Microbiol 53:859-862

58. Zhang T, Fang HHP (2006) Applications of real-time polymerase chain reaction for quantification of microorganisms in environmental samples. Appl Microbiol Biotechnol 70:281-289 